by V.K. Gahalaut ${ }^{1}$ and B.R. Arora ${ }^{2}$

\title{
Segmentation of seismicity along the Himalayan Arc due to structural heterogeneities in the under- thrusting Indian plate and overriding Himalayan wedge
}

${ }^{1}$ CSIR-National Geophysical Research Institute, Uppal Road, Hyderabad - 500 007, India. E-mail: vkgahalaut@yahoo.com ${ }^{2}$ Uttarakhand Council for Science \& Technology, 6, Vasant Vihar Phase I, Dehradun - 248 006, India.

The seismicity along the Himalayan arc varies significantly with some well defined patterns of segmentations. We show that the earthquakes along the Himalayan Seismic Belt (HSB) are influenced by the structural heterogeneities existing in the underthrusting Indian plate as well as by the presence of various north-south trending active rifts in the overriding wedge of the Himalaya. Model calculations of stress distribution show that stress change due to strain accumulation is more on moderately steeper fault, simulating the midcrustal ramp under the southern Higher Himalaya, than on the sub-horizontal thrust. Thus it is surmised that the presence of the ramp which connects the shallow section of seismically active detachment to the aseismically slipping deeper section of the detachment, causes high seismicity in the HSB region. It implies that the seismicity variation along the HSB may also be linked to the presence or absence of the ramp. Further, subsurface ridges on the down-going Indian plate probably control the rupture extent of the great Himalayan earthquakes. Over these ridges the seismicity of the HSB is generally low and it may imply that ramp may be absent in those regions. Finally, we show that the approximately north-south extending active rifts of the Tibetan and Higher Himalaya, cause stress shadow near their southern extent in the HSB which inhibit the occurrence of small and moderate magnitude thrust earthquakes.

\section{Introduction}

Seismicity in the Himalayan convergent plate margin varies both in space and time. Temporal variations in seismicity correspond to phases of earthquake cycle, season (Bollinger et al., 2007) and tidal variations (Tanaka et al., 2004; Cochran et al., 2004). Spatial variation in the seismicity along the arc may result from various causes, e.g., variation in the plate motion or convergence rate, lithology, rheology, heat productivity, etc. besides the structural complexity. The convergence rate accommodated in the Himalaya (Bilham et al., 1997; Jouanne et al., 1999; Banerjee and Burgmann, 2002; Banerjee et al., 2008; Ponraj et al., 2011; Jade et al., 2011; Ader et al., 2012) and the lithology (Yin, 2006) do not vary significantly along the arc and hence less likely to be the major factor to cause variation in the seismicity along the arc. Seismicity along the arc may also be influenced by the stress changes due to the interaction of faults in the Himalaya and Tibet, and by the occurrence of great and major earthquakes along the arc (Gahalaut et al., 2011), and by the deviatoric stresses due to topographic variation along the arc (Bollinger et al., 2004). However, variation in the rheology and structural complexity would influence the locking which may in turn cause variation in the seismicity. The structural complexities that appear to control the spatial variation in Himalayan seismicity include presence of ridges on the underthrusting Indian plate (Valdiya, 1976), the geometry of the detachment (Ni and Barazangi (1984), mid-crustal ramp (Pandey et al., 1995) as well as active rifts in the overriding Himalayan wedge (Armijo et al., 1986). Here in this article we discuss how the seismicity of the Himalayan arc is influenced by the underthrusting ridges of the Indian plate beneath the Indo-Gangetic plains, the presence of the mid-crustal ramp under the southern Higher Himalaya and rifts of the Higher and Tethys Himalaya.

\section{Earthquake Occurrence Processes in the Himalaya}

Along the $2500 \mathrm{~km}$ long Himalayan arc, representing the collisional boundary between the Indian and Eurasian plates (Fig.1), earthquake occurrence process has been explained using the model of subduction tectonics. Measurements of crustal deformation across the Himalaya reveals that about $2 \mathrm{~cm} /$ year of the India-Eurasia convergence (Bilham et al., 1997; Molnar, 1990) is accommodated in the Himalaya through stick and slip manner on seismically active detachment under the Outer and Lesser Himalaya (Seeber and Armbruster, 1981; Molnar, 1990). In the widely accepted seismotectonic models for the Himalaya, referred to as steady state 


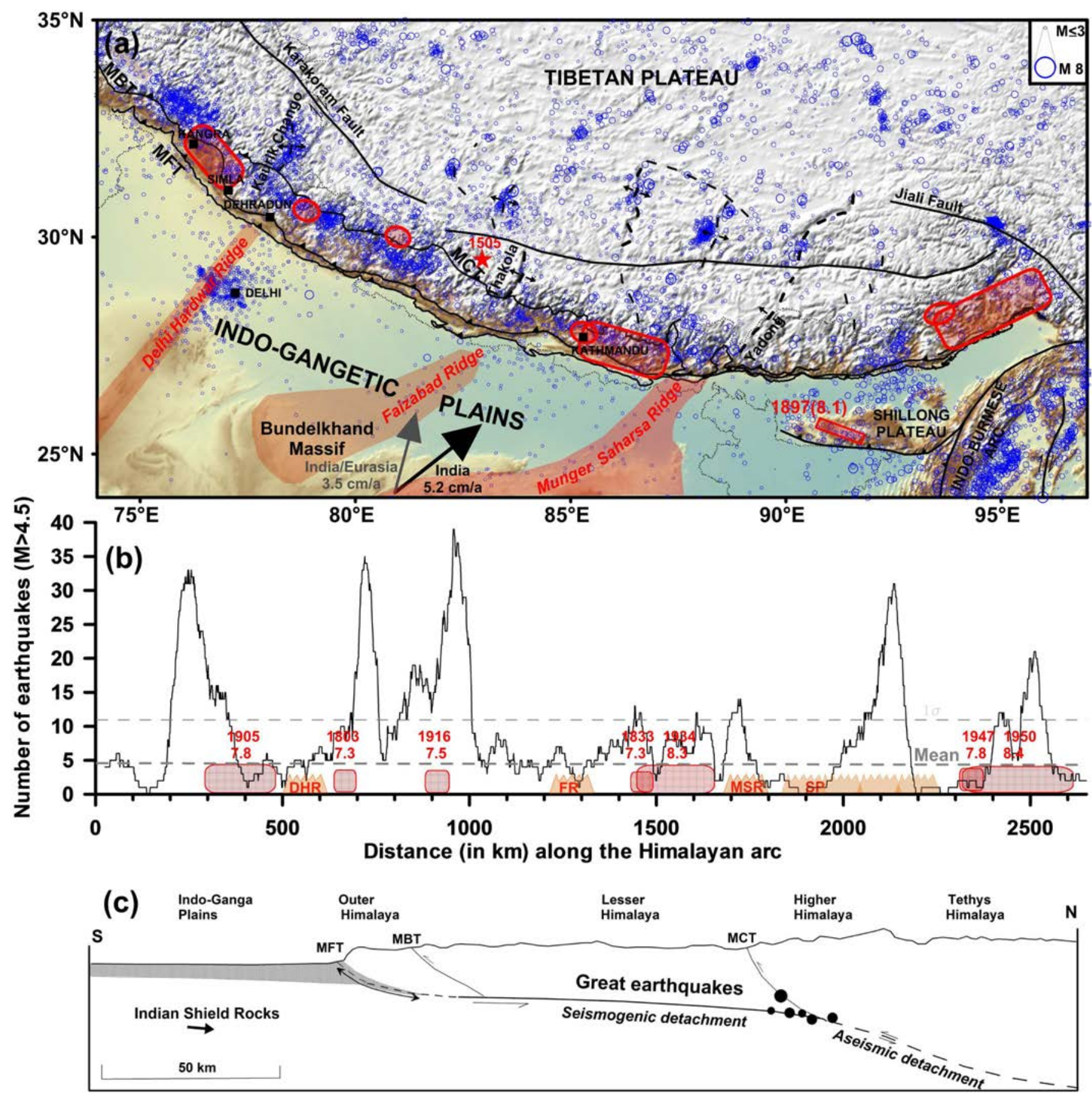

Figure 1. (a) Earthquakes (M>4.5) for the period of 1964 to 2010 (International Seismological Centre, ISC, catalogue) superimposed over a smooth topographic map the Himalaya and Tibetan region together with major faults (Gansser, 1964), rifts in the Tibetan plateau (Armijo et al., 1986; Yin, 2006) and subsurface ridges in the Indo-Gangetic plains (Sastri et al., 1971; Rao, 1973). The ruptures of earthquakes of $M>7.2$ of past 200 years in the Himalayan arc are shown by red rounded rectangles and ellipses and their year of occurrence and magnitudes are marked in (b). Ruptures of 1905 Kangra earthquake is after Wallace et al., (2005); 1803 after Rajendran and Rajendran (2004); 1833 Kathmandu and 1934 Nepal Bihar after Hough and Bilham (2008); and 1950 Assam earthquake after Molnar (1992). The 1897 Shillong Plateau (SP) earthquake (Bilham and England, 2001) is also shown for reference. The motion of India plate in global reference frame and with respect to Eurasia is shown by the arrows. (b) Variation of Himalayan seismicity $(M>4.5)$ in an overlapping and sliding $50 \mathrm{~km}$ wide window (sliding with a step of $1 \mathrm{~km}$ ) for the period between 1964 and 2010 along the curved Himalayan arc. The mean and $1 \sigma$ standard deviation of the seismicity in each window are marked with dashed line. Ruptures of great and major earthquakes (rounded red rectangles) and the subsurface ridges are also shown. (c) A general north-south vertical cross section across the Himalayan arc showing the seismically active and aseismically slipping detachment. The location of the HSB is also shown which is coincidental with the transition zone between the two detachments with contrasting nature that either connected through a flat or a mid-crustal ramp. DHR- DelhiHardwar ridge; FR-Faizabad ridge; MSR-Munger-Saharsa ridge; MFT- Main Frontal Thrust, MBT- Main Boundary Thrust; MCT- Main Central Thrust. 
and evolutionary models (Seeber and Armbruster, 1981; Ni and Barazangi, 1984), the great and major earthquakes in the Himalaya occur on the northward gently dipping (with a dip of about 5-10 seismically active detachment under the Outer and Lesser Himalaya (Fig. 1a). The presence of this part of the detachment, viewed as the contact surface between the underthrusting Indian plate and the overriding Himalayan wedge, is mainly inferred from the great earthquake source models (Seeber and Armbruster, 1981; Ni and Barazangi, 1984; Molnar, 1990), balanced geological cross sections (e.g., Schelling and Arita, 1991; Powers, 1998; Srivastava and Mitra, 1994) and limited studies based on active seismic experiment (e.g., Rajendra Prasad et al., 2011). Further north, under the Higher and Tethys Himalaya, the detachment slips aseismically (Fig. 1b). This part of the aseismically dipping detachment has been mapped extensively using various techniques, e.g., seismic (Zhao et al., 1993; Nabelek et al., 2009), receiver function (Rai et al., 2006; Kumar et al., 2006; Orshin et al., 2008; Singh et al., 2010; Zhao et al., 2010) and MT studies (Lammonier et al., 1999; Unsworth et al., 2005, Arora et al., 2007, Unsworth, 2010). Another notable feature of the Himalayan seismicity is that small and moderate magnitude earthquakes tend to concentrate in a narrow belt close to the downdip edge of the seismically active detachment (Seeber and Armbruster, 1981; Ni and Barazangi, 1984; Molnar, 1990) or more specifically in the transition zone between the seismically active detachment to the south and the aseismically slipping detachment to the north (Fig. 1a,c). This zone of concentrated earthquakes, which at surface is only 20$30 \mathrm{~km}$ wide and criss-crosses the Main Central Thrust (MCT) is referred to Himalayan Seismic Belt (HSB). In a few balanced geological cross sections, the transition zone which connects the subhorizontal detachment on either side (Gahalaut and Kalpna, 2001; Yin, 2006 and references therein) is marked with the mid-crustal ramp that dips at $20-30^{\circ}$. The role of the mid-crustal ramp in producing the more frequent occurrence of small and moderate earthquakes in narrow HSB is widely accepted (Pandey et al., 1995; Thakur et al., 1997), although its precise geometry as well the mechanism that causes these earthquakes are not understood. The ramp has not directly been mapped and is only inferred from the methods listed above. In many cross-sections and interpretations the two flats (the seismically active detachment under the Outer and Lesser Himalaya and the aseismically slipping detachment under the Higher and Tethys Himalaya) in the transition zone have been connected through detachment with gentle fault without any ramp with steeper dip. So the presence of the mid-crustal ramp is only conceptual and its location coincides with the HSB. Due to the regular up-gradation of seismic networks and inclusion of region specific velocity models, our understanding of the space-depth distribution of earthquakes (Kumar et al., 2009; Paul and Sharma, 2011), its variation along the arc, is improving continuously. In the present article, towards this quantification, hereafter the term Himalayan seismicity will be used to denote the earthquakes that occur between the HSB and the southernmost thrust, the Main Frontal Thrust (MFT). Figure 1b shows the variation of Himalayan seismicity along the curved Himalayan arc in terms of occurrence frequency of earthquakes of magnitude $\mathrm{M}>4.5$, calculated using running $50 \mathrm{~km}$ wide window (sliding with a step of $1 \mathrm{~km}$ ) for the period between 1964 and 2010.

\section{Influence of subsurface ridges on the Himalayan seismicity}

The subsurface ridges beneath the Indo-Gangetic plains and their possible continuations into the Himalaya (Valdiya, 1976) appear to influence the seismicity along the Himalayan arc as they appear to control the rupture extents of the major and great Himalayan earthquakes. These ridges under the Himalayan arc also influence the Himalayan seismicity (Fig.1a, b and Fig.2).

\section{Control on rupture extent of great and major Himalayan earthquakes}

Gahalaut and Kundu (2012) demonstrated that the rupture extents

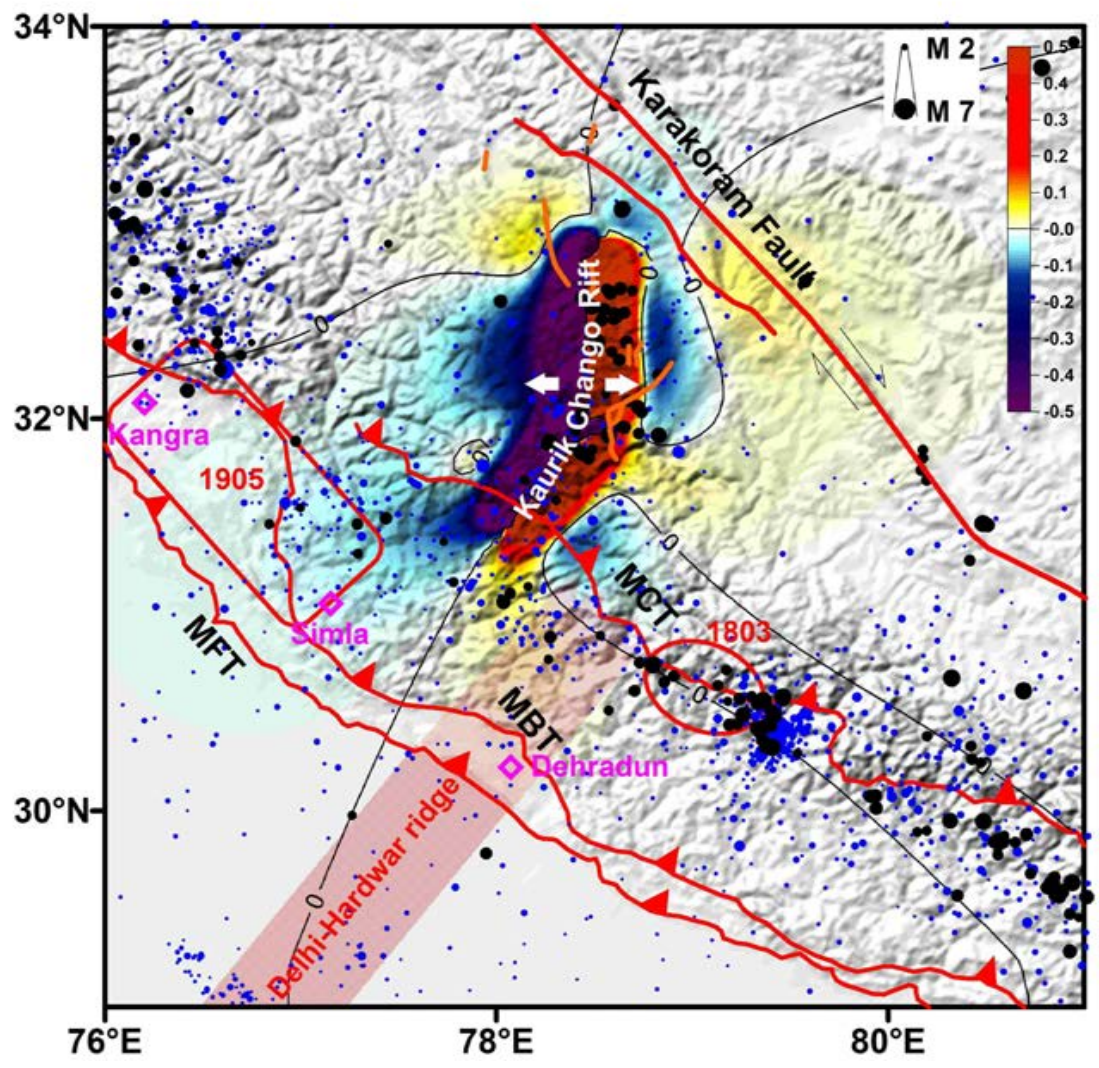

Figure 2. Seismicity of the NW Himalaya. Earthquakes are from the EHB catalogue (from ISC) for the period of 1964 to 2010 (black filled circles). The lower cut-off magnitude in this catalogue is about 4.5. The lower magnitude $(M>2.5)$ earthquakes (blue filled circles) during 1999-2010 are from the local seismological network operated by the India Meteorological Department and Wadia Institute of Himalayan Geology in the NW Himalaya. Note that the narrow HSB, related to the crustal ramp, is marked by the low seismicity in the Simla region and over the extended part of the DHR. The superimposed colour image shows the change in Coulomb stress (in bar) on the Himalayan detachment (with thrust motion on gently dipping fault) due to normal slip on the Kaurik Chango rift. It appears that the active rifting in the northsouth direction casts stress shadow on the part of the Himalayan detachment which suppresses the seismicity in the Simla region. 
of great and major Himalayan earthquakes were probably influenced by the subsurface ridges extending into the Himalaya. They found that the rupture extents of earthquakes of past 200 years, namely the September 1, 1803 Garhwal (M 7.7); August 26, 1833 Kathmandu (M 7.7); April 4, 1905 Kangra (M 7.8); August 28, 1916 western Nepal (M 7.3); January 15, 1934 Nepal-Bihar; July 29, 1947 Assam and August 15, 1950 Assam earthquakes (Fig.1) (Seeber and Armbruster, 1981; Ni and Barazangi, 1984; Molnar, 1990; Gahalaut, 2008), are probably controlled by the three subsurface ridges or the basement highs (Fig.1), namely the Monghyr (or Munger) Saharsa ridge, Faizabad ridge, and the Delhi-Hardwar ridge (Sastri et al., 1971; Rao, 1973) (Fig.1). The characteristics of the Delhi-Hardwar ridge have been studied fairly well. Presence of high electrical conductivity structure aligned with the Delhi-Hardwar ridge has been indicated by the synthesis of various geomagnetic induction features revealed by large-scale magnetometer array studies (Arora et al., 1982; Arora and Mahashabde, 1987). Imaged as domal structure at a depth of $15 \mathrm{~km}$, its high electrical conductivity was attributed to the mantle derived fluids (Arora, 2001). More recently, Wang and Bilek (2011) have shown that the ridges or seamounts marked by high degree of fractured network are characterised by the heterogeneous friction, leading to heterogeneous coupling due to which the rupture do not propagate through them. Given that presence of fluids in the fractured domain strongly influence the rheology of rocks, the DHR like ridges with increased ductility and characterised by heterogeneous friction would inhibit the propagation of earthquake rupture through them. Such visualisation corroborates the conclusion of Gahalaut and Kundu (2012) that the ridges acted as a barrier to the incoming rupture front due to which the rupture of Great Earthquakes along the Himalayan arc were stalled and terminated at the ridges. Future high resolution imaging of geometry and rheology of the ridges together with the dynamic rupture characteristics of the past and future great earthquakes will facilitate further quantification. It is possible that the precise GPS measurements of crustal deformation are also expected to show some heterogeneity in the displacement vectors over these ridges. However, the present day measurements in the Himalaya (Ponraj et al., 2011; Jade et al., 2011; Ader et al., 2012) are sparse to resolve any influence of these ridges on the surface displacement field.

\section{Seismicity along the ridges}

The seismicity of the Indo-Gangetic plains is very low and the ridges under the Indo-Gangetic plains have not produced a major earthquake in past few centuries. However, all the three ridges are characterised by low and moderate magnitude earthquakes (Chandra, 1978; 1992, Fig.7 of Ader et al., 2012 and also our Fig. 2). The seismic character of the Delhi-Hardwar ridge has become more conspicuous with the induction of more seismological stations, particularly, a local network around Delhi region (Bansal and Verma, 2012). Similarly, the seismicity low along the Faizabad ridge (Fig. 1a, b) has been brought out clearly by the installation of a dense seismic network in Nepal (Ader et al., 2012). However, the status of seismicity along the extension of the Monghyr-Saharsa ridge into the Sikkim Himalaya is not conspicuous, probably due to its alignment with the seismically active Yadong rift. Immediately east of Sikkim Himalaya in the Bhutan and Arunachal region, the seismicity appears to be low (Drukpa et al., 2006; Valesco et al., 2007; Gahalaut et al., 2011). In summary, along the large part of the Himalayan arc where the seismicity is generally high and concentrated in a narrow belt all along the HSB, it appears to be relatively low and diffused above these ridges (Figs.1b, 2, and Fig.7 of Ader et al., 2012). Therefore, an important issue that appears to be linked indirectly with the ridges is the level of seismicity in the HSB and its variation along the Himalayan arc.

\section{Influence of ramp on the seismicity of the HSB}

The confinement of the moderate and small seismicity along the Himalayan arc to a narrow HSB is attributed to the presence or absence of the mid-crustal ramp under the southern Higher or northern Lesser Himalaya. The ramp connects the shallow and seismically active detachment to the south with the deeper and aseismically slipping detachment to the north. To validate whether the presence of the ramp influences the seismicity of the HSB, we calculate the stress change due to locking of the seismically active sub-horizontal detachment under the Outer and Lesser Himalaya (Fig.3). This model is mathematically equivalent to the one in which slip is assumed to occur at the deeper part of the detachment on which slip occurs aseismically. We assume the dip of the aseismically slipping detachment as $10^{\circ}$ and slip rate as $2 \mathrm{~cm} /$ year which is the long term convergence rate accommodated at the Himalaya (Molnar, 1990). We resolve the stress on the thrust planes with dip $10^{\circ}$ and $25^{\circ}$. The two cases simulate the case in which there is no ramp and hence the coulomb stress is resolved on the sub-horizontal detachment with dip of about $10^{\circ}$ and the case in which there is a ramp with a dip of $25^{\circ}$. As the seismicity of the HSB is confined in a narrow belt of 20-30 km wide under the southern Higher and northern Lesser Himalaya, we focus on the region updip of the aseismically slipping detachment (box in Fig.3). Similar to Cattin and Avoauc (2001) and Gahalaut and Kalpna (2000) analysis we also find that the Coulomb stress is positive in that region which implies that the process of strain accumulation promotes earthquakes of the HSB. However, the notable result here is that the Coulomb stress is higher for the case when they are resolved on $25^{\circ}$ plane and it is dependent on the frictional coefficient $(\mu)$. For lower friction coefficient the Coulomb stress is higher in both cases. It is noted that for lower friction coefficient ( $\mu=0.2$ ), Coulomb stress is about $20 \%$ higher in case of ramp ( $25^{\circ}$ plane) in comparison to the case when no ramp is assumed, e.g., in Fig.3, at a distance of $90 \mathrm{~km}$ and depth of $15 \mathrm{~km}$, the stress change is about 0.976 bar for ì as 0.2 in case of $10^{\circ}$ dip whereas it is 1.207 bar in case of $25^{\circ}$ dip. Higher coulomb stress will lead to higher level of seismicity. Thus the high seismicity level in the HSB along the arc may be a proxy to the presence of the ramp and its dip.

\section{Signatures of Ridge-Ramp interactions on seismicity}

Although the nature of subsurface geometry in the transition zone remains unresolved, in a few balanced cross sections, presence of a mid-crustal ramp has been suggested. Presence of such a ramp structure was suggested from the earthquakes located by the Nepal seismic network (Pandey et al., 1995). Evidence of the ramp structure is also suggested by numbers of magnetotelluric investigations in Garhwal and Nepal Himalaya (Reddy and Arora, 1993; Lemonnier et al., 1999; Israil et al., 2010; Rawat, 2011). These studies show that north dipping mid-crustal low resistivity layer which is a persistence feature of the Sub- and Lesser Himalaya show discontinuous down 

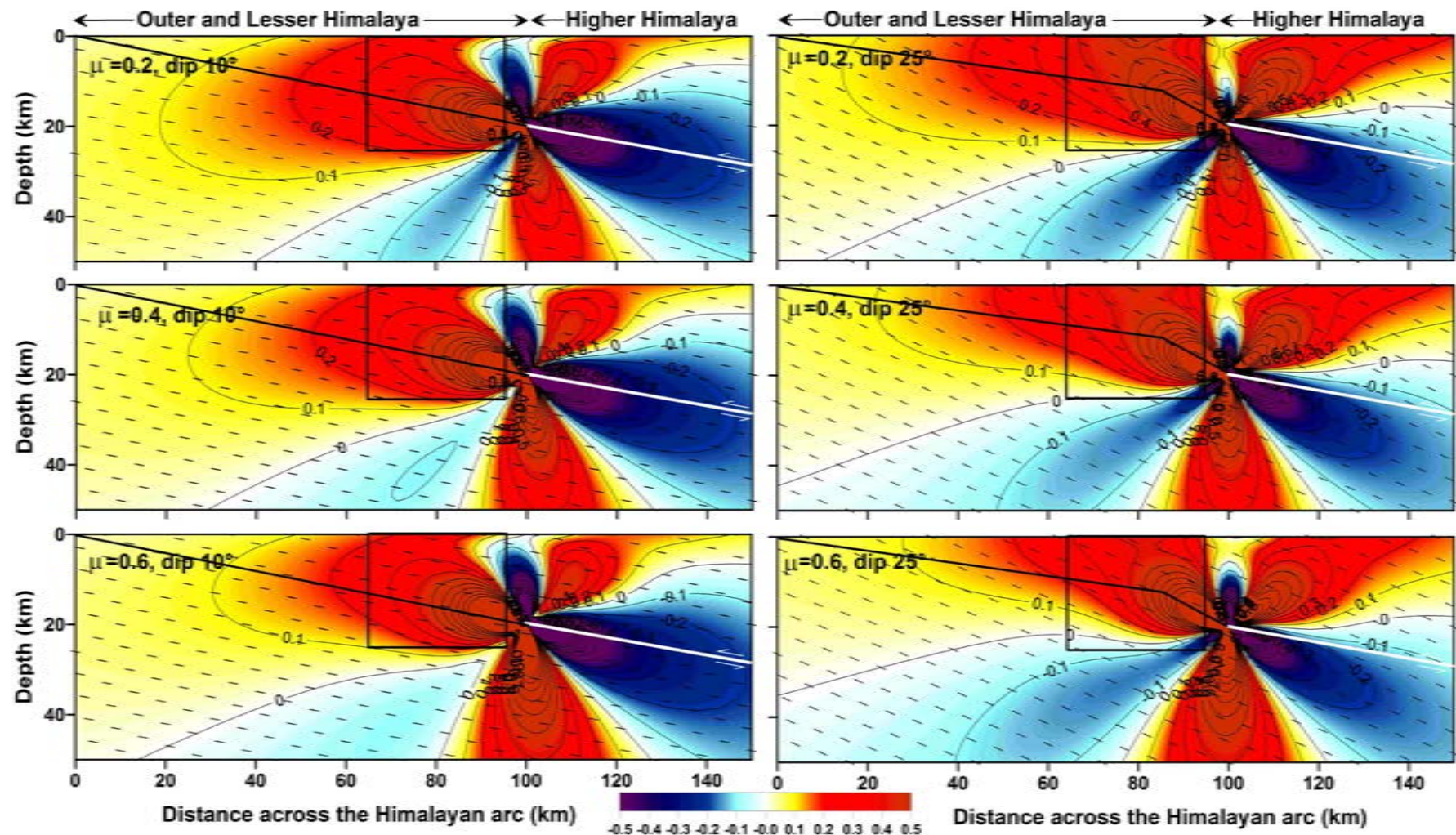

Figure 3. A conceptual model of change in the Coulomb stress (in bar) due to strain accumulation on the detachment (black line) under the Outer and Lesser Himalaya in a vertical cross section. The aseismically slipping detachment under the Higher Himalaya is shown by white line. In the right panels two parallel segments of the detachment are displaced and connected by a ramp with a dip of $25^{\circ}$, simulating a case of ramp whereas in the left panels they run as single plane, simulating no-ramp case. For both cases, the variations are shown for varying values of frictional coefficient $(\mu)$. In the left panels the stresses are resolved on thrust planes with a dip of $10^{\circ}$ (shown with short lines) whereas in the right panels the stresses are resolved on thrust planes with dip of $25^{\circ}$ (shown with short lines). The box in each panel shows the location of occurrence of earthquakes in the HSB. The change in the Coulomb stress in the box increases with decreasing $\mu$. Note that the change in Coulomb stress is more when resolved on planes with dip of $25^{\circ}$ (ramp) as compared to that on planes with dip $10^{\circ}$ (no ramp, or flat).

throw around the MCT coincident with the HSB. Such suggestion on the presence of the ramp is further corroborated by the clustering pattern of earthquakes recorded by a recently established 10-stations network in Garhwal Himalaya (Arora et al., 2008; Paul and Sharma, 2011). The epicenter distribution clearly defines the HSB with a narrow belt straddling the surface trace of the MCT (Fig.2). However, it is striking that well defined concentration of moderate, small and micro earthquakes in the HSB is highly diffused in the central part of the Garhwal Himalaya. It is interesting to note that the extent of low seismicity region coincides with the width of the electrical conductive structure found to extend from the Indo-Gangetic Plains into the Outer and Lesser Himalaya. Numerical modelling of induction response approximates the electrical structure as an asymmetric domal upwarp in middle and lower crust with approximate width of $65 \mathrm{~km}$ (Arora, 1990). This correspondence of the low seismicity zone embedded in the HSB with arc perpendicular structure raises the possibility that ramp may not be present under the parts of the Himalayan arc where the subducting subsurface ridges interact with the later. The presence of ridges along the Himalayan arc may cause along-strike variation in the thickness of sediments down-going with the underthrusting Indian plate. Akin to subduction zones with varying sediment flux (Ruff, 1989; Polet and Kanamori, 2000; Gahalaut, 2010), the variations in the thickness of sediments may produce along-strike inequality in the coupling of the down-going Indian plate rocks with the overlying Himalayan wedge, which may analogously be manifested by the segmentation of the seismicity both in large and small magnitude earthquakes. In case of the Himalaya arc, the ridges with thin sediment cover appear to mark the zone of low or heterogeneous coupling and hence exhibit low seismicity and also act as barrier to the earthquake ruptures (Wang and Bilek, 2011).

\section{Rifts in the Higher Himalaya and their influence on the HSB}

Several north-south extending active rifts have been mapped on the Tibetan plateau (Fig.1), which extend from Tibetan plateau to the Higher Himalaya (Armijo et al., 1986). Although their extension in further south direction is not established due to lack of surface expression, segmentation of the overriding Himalayan wedge due to these rifts may also control rupture extent of major earthquakes of the Himalaya (Gahalaut and Kundu, 2011). The ongoing earthquake occurrence and associated crustal deformation on these active rifts may also influence the Himalayan seismicity by altering the stress state. Among all such cases, the most notable is the unambiguous decrease in seismicity level of earthquakes of $M>4.5$ in the Simla 
region of the Himalayan arc, that is located west of the Delhi-Hardwar region and between the 1905 Kangra and 1803 earthquake ruptures (Fig.1). On either side of the region along the Himalayan arc, the seismicity level is higher than this region (Fig.3). This feature can also be seen even for the lower magnitude earthquakes which are recorded by the local networks of Wadia Institute of Himalayan Geology and Indian Meteorological Department (Fig.2). Among several other possibilities including the fact that the low seismicity could be because the region has released stress during 1905 Kangra earthquake, we hypothesised that this decrease is due to the active Kaurik Chango rift in the north. This rift is the most active amongst all the rifts and extends well into the Himalayan arc. An earthquake of magnitude 6.8 with focal depth of less than $15 \mathrm{~km}$ occurred in this rift zone on January 19, 1975, referred as the Kinnaur earthquake, which is the largest earthquake that has occurred on any of these rifts of the Tethys Himalaya in past fifty years. The earthquake involved normal motion on the north-south oriented steep plane (Khattri et al., 1978). Since 1973, more than fifty earthquakes of $M>4.5$ have occurred along this rift and the focal mechanisms of these earthquakes is similar to that of the Kinnaur earthquake. To test whether the ongoing earthquake occurrence and associated crustal deformation on the Kaurik Chango rift influence the seismicity of the HSB, we calculated the stress change due to the earthquakes activity in this rift zone and investigate nature of stress perturbation onto the Himalayan detachment (Fig.2). The entire calculations are carried out under the assumption that earthquake related slip is accommodated predominantly by normal motion on the north-south oriented steep plane, representing the Kaurik Chango rift. The length and depth extent of the fault are constrained by the earthquake distribution in the region which we assume as 100 and $25 \mathrm{~km}$ respectively. Using the earthquake magnitudes, their seismic moments, and scaling relations (Wells and Coppersmith, 1994), we estimated that the average slip rate on this rift is about $1 \mathrm{~cm} /$ year. It turns out that the Simla region of the Himalayan arc is indeed under the stress shadow of the Kaurik-Chango rift. Thus the ongoing earthquake activity at the Kaurik-Chango rift decreases the stress level on the detachment in the region of HSB. We surmise that in a similar way other rifts of the Himalayan region also influence the Himalaya seismicity. Although the activity along these rifts is attributed to the eastward extrusion of the Tibetan plateau, our calculations show that the earthquakes on the seismically active detachment also promote earthquakes in these rifts.

Additionally the occasional great and major earthquakes of the Himalayan arc and adjoining region might also be influencing the seismicity of the Himalayan arc. A probable example for such a case is the influence of the 1897 Shillong plateau earthquake on the seismicity of the Himalayan arc to the north. The stress shadow caused by the 1897 Shillong Plateau earthquake has been ascribed to cause low seismicity in the Bhutan Himalaya (Gahalaut et al., 2011). The stress shadow might have also caused the rupture termination of the 1934 Nepal Bihar and 1950 Assam earthquake, along their eastern and western rupture edges, respectively.

\section{Conclusions}

We have analysed here the spatial variation of Himalayan seismicity and demonstrated that along-arc segmentation of seismic activity may be related to the structural complexities in the underthrusting Indian plate itself arising from the interaction of the subsurface ridges and active rifts in the overriding Himalayan wedge. Following conclusions may be drawn from the analysis.

1. Calculations favour that the presence of the mid-crustal ramp, connecting the seismically active detachment and the aseismically slipping detachment, enhances the stress in the transition zone where earthquakes of HSB are concentrated. High level of seismicity in the HSB seems to be a good proxy to the presence of the ramp.

2. The observation that seismicity appears to be diffused in the section of the HSB where subsurface ridges extend into the Himalaya implies that the ramp is probably absent under the parts of the Himalayan arc where the ridges are present.

3. The stress change resulting from the active rifts of the Higher Himalayan causes shadow zone near their southern extent which partly suppresses the seismicity along some sections of the HSB.

\section{Acknowledgements}

The earthquake data have been taken from the International Seismological Centre global catalogue (http://www.isc.ac.uk/ iscbulletin/search/catalogue/). Two anonymous reviewers provided extremely constructive comments. We thank the editor for being very encouraging and prompt.

\section{References}

Ader, T., Jean-Philippe Avouac, Jing Liu-Zeng, Hélène Lyon-Caen, Laurent Bollinger, John Galetzka, Jeff Genrich, Marion Thomas, Kristel Chanard, Soma Nath Sapkota, Sudhir Rajaure, Prithvi Shrestha, Lin Ding, and Mireille Flouzat, 2012, Convergence rate across the Nepal Himalaya and interseismic coupling on the Main Himalayan Thrust: Implications for seismic hazard. Journal of Geophysical Research, v. 117, B04403, doi:10.1029/2011JB009071.

Armijo, R., Tapponnier, P., Mercier, J.L., and Tong-Lin, H., 1986, Quaternary extension in south Tibet: field observations and tectonic implications. Journal of Geophysical Research, v. 91, pp. 13803-13872.

Arora, B.R., 1990, Magnetometer array studies in India: Present status, data interpretation and assessment of numerical modelling results, Special issue: Geomagnetic methods and lithospheric structures. Ed. B.P. Singh. Proceedings Indian Academy of Sciences (Earth and Planetary Science), v. 99, pp. 693-716.

Arora, B. R. and M.V. Mahashabde, 1987, A transverse conductive structure in the northwest Himalaya. Physics of Earth Planetary Interiors, v. 45, pp. 119-127.

Arora, B.R., Unsworth, M. J. and Rawat, G., 2007, Deep resistivity structure of the northwest Indian Himalaya and its tectonic implications. Geophysics Research Letters, v. 34, L04307, doi:10.1029/ 2006 GL029165.

Arora, B.R., Kumar, N., Gautam Rawat and Ajay Paul, 2008, A Peep into the Himalayan seismicity. Memoir Geological Society of India, no. 72, pp. 29-46.

Arora, B. R., F.E.M. Lilley, M.N. Sloane, B.P. Singh, B.J. Srivastava and S.N. Prasad, 1982. Geomagnetic induction and conductive structures in northwest India. Geophysical Journal Royal Astronomical Society, v. 69, pp.459-475.

Banerjee, P. and Burgmann, R., 2002, Convergence across the northwest Himalaya from GPS measurement. Geophysics Research Letters, v. 2913, pp. 301-304.

Banerjee, P., R.Burgmann, B. Nagarajan, and E. Apel, 2008. Intraplate deformation of the Indian subcontinent. Geophys. Res. Lett., v.35, L18301, doi:10.1029/2008GL035468.

Bansal, B.K., and Verma 2012, M., The M 4.9 Delhi earthquake of 5 March 
2012. Current Science, v. 102, pp. 1704-1708.

Bilham, R., Larson, K., Freymueller, J., and members, 1997, GPS measurements of present-day convergence across the Nepal Himalaya. Nature, v. 386, pp. 61-64.

Bilham, R. and England, P., 2001, Plateau pop-up in the 1897 Assam earthquake. Nature, v.410, pp.806-809.

Bollinger, L., Avouac, J.P., Cattin, R., and Pandey, M.R., 2004, Stress buildup in the Himalaya. Journal of Geophysical Research, v. 109, B11405, doi:10.1029/2003JB002911.

Bollinger, L., Perrier, F., Avouac, J.-P., Sapkota, S., Gautam, U., and Tiwari, D.R., 2007, Seasonal modulation of seismicity in the Himalaya of Nepal. Geophysical Research Letter, v. 34, L08304, doi:10.1029/ 2006 GL029192.

Cattin, R., and Avouac, J.-P., 2000, Modeling of mountain building and the seismic cycle in the Himalaya of Nepal. Journal Geophysical Research, v. 105, pp. 13389-13407.

Chandra, U., 1978, Seismicity, earthquake mechanisms and tectonics along the Himalayan range and vicinity. Physics of Earth Planetary Interiors, v. 16, pp. 109-131.

Chandra, U., 1992, Seismotectonics of Himalaya. Current Science, v. 62, pp. 40-71.

Cochran, E. S., Vidale, E. J., and Tanaka, S., 2004, Earth tides can trigger shallow thrust fault earthquakes, Science, v. 306, pp. 1164-1166.

Drukpa, D., Velasco, A.A., Doser, D.I., 2006, Seismicity in the Kingdom of Bhutan 1937-2003, evidence for crustal transcurrent deformation. Journal Geophysical Research, v. 111, B06301. doi:10.1029/2004JB003087.

Gahalaut, V.K., 2008, Major and great earthquakes and seismic gaps in the Himalayan arc. Memoir Geological Society of India, Golden Jubilee Volume, no. 66, pp. 373-393.

Gahalaut, V.K., 2010, Probable role of sediments in blinding the rupture, lesson from the 2004 Sumatra-Andaman earthquake and implication for the Himalayan earthquakes. Current Science, v. 9811, pp. 1518-1520.

Gahalaut, V.K. and Kalpna, 2000, On the occurrence of small and moderate earthquakes of the Himalayan seismic belt. Current Science, v. 79, pp. 101-103.

Gahalaut, V.K. and Kalpna, 2001, Himalayan mid crustal ramp. Current Science, v.81, pp.1641-1646.

Gahalaut, V.K. and Kundu, B., 2012, Possible influence of subducting ridges on the Himalayan arc and on the ruptures of great and major Himalayan earthquakes., Gondwana Research, v. 21, pp.1080-1088, doi:10.1016/ j.gr.2011.07.021.

Gahalaut, V. K., Shikha Rajput and Kundu, B., 2011, Low seismicity in Bhutan Himalaya and the 1897 Shillong Plateau earthquake. Physics Earth Planetary Interiors, v. 186, pp. 97-102. doi:10.1016/j.pepi.2011.04.009.

Gansser, A., 1964, Geology of the Himalaya. Interscience, New York, N.Y., 298 pp.

Hough, S., and Bilham, R., 2008, Site Response of the Ganges Basin inferred from re-evaluated Macroseismic Observations from the M8.1 Shillong 1897, M7.8 Kangra 1905 and 1934 Nepal M8.1 earthquakes. Journal of Earth System Science, v.117, S2, pp.773-782.

International Seismological Centre, 2009, EHB Bulletin, http://www.isc.ac.uk, Internatl. Seis. Cent., Thatcham, United Kingdom.

Israil, M., Tyagi, D., Gupta, P., and Niwas, S. 2008, Investigations for imaging electrical structure of Garhwal Himalaya corriddor, Uttarakhand, India. Journal of Earth System Science, v. 117, pp. 189-200.

Jade, S., Raghavendra Rao, H.J., Vijayan, M.S.M., Gaur, V.K., Bhatt, B.C., Kumar, K., Saigeetha Jaganathan, Ananda, M.B., and Dileep Kumar, P., 2011, GPS-derived deformation rates in northwestern Himalaya and Ladakh. International Journal of Earth Sciences, v. 100, pp. 1293-1301.

Jouanne, F., Mugnier, J.L., Pandey, M., Gamond, J.F., Le Fort, P., Serrurier, P., Vigny, C., Avouac, J.P. and members, 1999, Oblique convergence in Himalaya of western Nepal deduced from preliminary results of GPS measurements. Geophysics Research Letter, v. 26, pp. 1933-1936.

Khattri, K.N., Rai, K., Jain, A.K., Sinvhal, H., Gaur, V.K., and Mithal, R.S., 1978, The Kinnaur earthquake Himachal Pradesh India of 19 January 1975. Tectonophysics, v. 49, pp. 1-21.
Kumar, P., Yuan, X., Kind, R., and Ni, J., 2006, Imaging the colliding Indian and Asian lithospheric plates beneath Tibet. Journal Geophysical Research, v. 111, 10.1029.

Molnar, P., 1990, A review of the seismicity and the rates of active underthrusting and deformation at the Himalaya. Journal of Himalayan Geology, v. 12, pp. 131-154.

Lemmonier, C., et al. 1999, Electrical structure of the Himalaya of Central Nepal: high conductivity around the mid-crustal ramp along the Main Himalayan Thrust. Geophysics Research Letter, v. 26, pp. 3261-3264.

Nábelek, J., Hetényi, G., Vergne, J., Sapkota, S., Kafle, B., Jiang, M., Su, H., Chen, C., Huang, B.S., Team, Hi-CLIMB, 2009. Underplating in the Himalaya-Tibet collision zone revealed by the Hi-CLIMB experiment. Science, v. 325, pp. 1371-1374. doi:10.1126/science.1167719.

Ni, J., and Barazangi, M., 1984, Seismotectonics of the Himalayan collision zone: Geometry of the underthrusting Indian plate beneath the Himalaya. Journal Geophysics Research, v. 89, pp. 1147-1163.

Oreshin, S., Kiselev, S., Vinnik, L., Surya Prakasam, K., Rai, S.S., Makeyeva, L., and Savvin, Y., 2008, Crust and mantle beneath western Himalaya, Ladakh and western Tibet from integrated seismic data. Earth and Planetary Science Letters, v. 271, pp. 75-87

Pandey, M.R., Tandukar, R.P., Avouac, J.P., Lave, J., and Massot, J.P., 1995, Interseismic strain accumulation in the Himalayan crustal ramp in Nepal. Geophysics Research Letter, v. 22, pp. 741-754.

Paul, A. and Sharma, M.L., 2011, Recent earthquake swarms in Garhwal Himalaya: A precursor to moderate to great earthquakes in the region. Asian Journal of Earth Science, v. 42, pp. 1179-1186.

Polet, J., and Kanamori, H. 2000, Shallow subduction zone earthquakes and their tsunamigenic potential. Geophysical Journal International, v. 142, pp. 684-702.

Ponraj, M., Miura, S., Reddy, C.D., Amirtharaj, S., and Mahajan, S.H., 2011, Slip distribution beneath the Central andWestern Himalaya inferred from GPS observations. Geophysical Journal International, v. 185, pp. 724 736 doi: 10.1111/j.1365-246X.2011.04958.x

Powers, P.M., Lillie, R.J., and Yeats, R.S., 1998, Structure and shortening of the Kangra and Dehra Dun reentrants, sub-Himalaya, India. Geological Society of America Bulletin, v. 110, pp. 1010-1027.

Rai, S.S., Priestley, K., Gaur, V.K., Mitra, S., Singh, M.P., and Searle, M., 2006, Configuration of the Indian Moho beneath the NW Himalaya and Ladakh. Geophysical Research Letters, v. 33 15, L15308.

Rajendra Prasad, B., Simon L. Klemperer, Vijaya Rao, V., Tewari, H.C., and Prakash Khare, 2011, Crustal structure beneath the Sub-Himalayan foldthrust belt, Kangra recess, northwest India, from seismic reflection profiling: Implications for Late Paleoproterozoic orogenesis and modern earthquake hazard. Earth and Planetary Science Letters, v. 308, pp. 218228

Rajendran, C.P., and Rajendran, K., 2005, The status of central seismic gap: A perspective based on the spatial and temporal aspects of the large Himalayan earthquakes. Tectonophysics, v. 395, pp. 19-39.

Rao Ramachandra, M.B., 1973, The subsurface geology of the IndoGangetic plains. Journal of the Geological Society of India, v. 14, pp. 217-242.

Rawat, G., 2011, Electrical conductivity imaging of the Uttarakhand Himalaya using MT method, Ph.D thesis, Indian Institute of Technology, Roorkee.

Ruff, L.J., 1989, Do trench sediments affect great earthquake occurrence in subduction zones? Pure and Applied Geophysics, v. 129, pp. 263282.

Sastri, V.V., Bhandari, L.L., Raju, A.T.R., and Datta, A.K., 1971, Tectonics framework and subsurface stratigraphy of the Ganga basin. Journal of the Geological Society of India, v. 12, pp. 232-233.

Schelling, D., and Arita, K., 1991, Thrust tectonics, crustal shortening, and the structure of the far-eastern Nepal Himalaya. Tectonics, v. 105, pp. 851-862, doi:10.1029/91TC01011.

Seeber, L. and J. Armbruster, 1981, Great detachment earthquakes along the Himalayan Arc and long-term forecasting. In: D.W. Simpson and P.G. Richards editors, Earthquake Prediction: An International Review, Maurice Ewing Series, American Geophysical Union, v. 4, pp. 259-277. 
Singh, A., Kumar, M.R. and Raju, P.S., 2010, Seismic structure of the underthrusting Indian crust in Sikkim Himalaya. Tectonics, v. 29 6, TC6021.

Srivastava, P., and Mitra, G., 1994, Thrust geometries and deep structure of the outer and lesser Himalaya, Kumaon and Garhwal India: Implications for evolution of the Himalayan fold-and -thrust-belt. Tectonics, v. 13, pp. 89-109.

Tanaka, S., Ohtake, M. and Sato, H., 2004, Tidal triggering of earthquakes in Japan related to the regional tectonic stress. Earth Planets Space, v. 565, pp. 511-515.

Unsworth, M.J., Jones, A.G., Wei, W., Marquis, G., Gokarn, S.G., Spratt, J.E. and Paul Bedrosian, John Booker, Chen Leshou, Greg Clarke, Li Shenghui, Lin Chanhong, Deng Ming, Jin Sheng, Kurt Solon, Tan Handong, Juanjo Ledo and Brian Roberts for The INDEPTH-MT team 2005, Crustal rheology of the Himalaya and Southern Tibet inferred from magnetotelluric data, Nature, v. 438, pp. 78-81.

Unsworth, M., 2010, Magnetotelluric Studies of Active Continent-Continent Collisions, Surv Geophys, v. 31, pp. 137-161, DOI 10.1007/s10712009-9086-y

Valdiya, K.S., 1976, Himalayan transverse faults and folds and their parallelism with the subsurface structures of the north Indian plains. Tectonophysics, v. 32, pp. 353-386.

Velasco, A.A., Gee, V.L., Rowe, C., Grujic, D., Hollister, L.S., Hernandez, D., Miller, K.C., Tobgay, T., Fort, M., and Harder, S., 2007 Using small, temporary seismic networks for investigating tectonic deformation: brittle

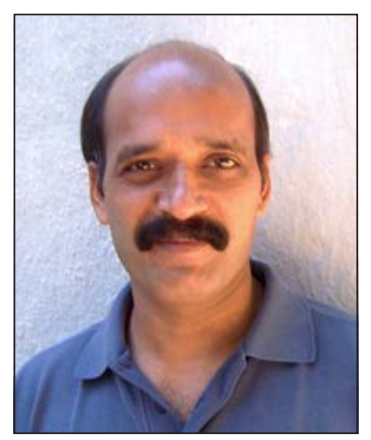

Vineet $\mathbf{K}$ Gahalaut received M.Tech. and Ph.D. degrees from University of Roorkee (now IIT-Roorkee) in 1989 and 1995, respectively. Currently he is Principal Scientist at NGRI, Hyderabad. His research areas include Tectonic Geodesy and Seismology. He has established GPS networks in Andaman-Nicobar subduction zone, Indo-Burmese wedge, GarhwalKumaun Himalaya, Godavari failed rift region and Koyna Warna region. He is a recipient of INSA Young Scientist award (1997), CSIR Young Scientist (2001), MS Krishnan gold medal by IGU (2006) and PRL award (2012). deformation and evidence for strike slip faulting in Bhutan. Seismological Research Letters, v. 78, pp. 446-453.

Wallace, K., Bilham, R., Blume, F., Gaur, V.K. and Gahalaut, V., 2005, Geodetic constraint of the 1905 Kangra earthquake and interseismic deformation 1846-2001. Geophysical Research Letters, v. 32: L15307, doi:10.1029/2005GL022906.

Wang Kelin and Susan L. Bilek, 2011, Do subducting seamounts generate or stop large earthquakes? Geology, v. 39, pp. 819-822, doi:10.1130/ G31856.1

Wells, D.L. and Coppersmith, K.J., 1994, New empirical relationships among magnitude, rupture length, rupture width, rupture area, and surface displacement. Bulletin Seismological Society of America, v. 84, pp. 9741002.

Yin, A., 2006, Cenozoic tectonic evolution of the Himalayan orogen as constrained by along-strike variation of structural geometry, exhumation history, and foreland sedimentation. Earth-Science Reviews, v. 76, pp. $1-131$.

Zhao, J., Xiaohui Yuan, Hongbing Liu, Prakash Kumar, Shunping Pei, Rainer Kind, Zhongjie Zhang, Jiwen Teng, Lin Ding, Xing Gao, Qiang Xu, and Wei Wang, 2010, The boundary between the Indian and Asian tectonic plates below Tibet. Proceedings of the National Academy of Sciences, v. 107 25, 11229.

Zhao, W., Nelson, K.D., and Project INDEPTH Team, 1993, Deep seismic reflection evidence for continental underthrusting beneath southern Tibet. Nature v. 366, pp. 557-559. doi:10.1038/366557a0.

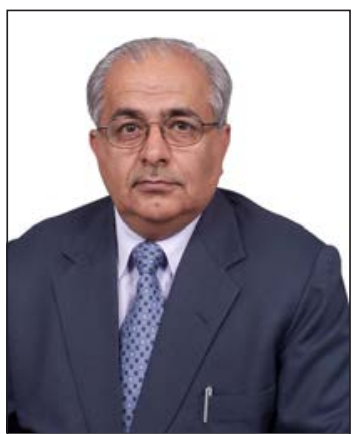

B.R. Arora is CSIR- Emeritus Scientist at Uttarakhand State Council for Science \& Technology. He has long been engaged in imaging the deep structures of the Himalayan collision zone using magnetotelluric (MT) and passive seismology. His more recent accomplishment has been the establishment of Multi-Parameter Geophysical Observatory for earthquake precursory research in integrated manner. Prof. Arora had worked at IIG, Mumbai and as Director at WIHG, Dehradun. He has been the recipient of National Mineral Award (2002) and IGUElectrotek and Geometrics Endowment Medal (2008). 